KEIDING, H. (1989): Seed collection from teak plantations at Mtibwa and Longuza, Tanzania. Report/note $7 \mathrm{p}$. Danida Forest Seed Centre, Denmark.

KJAER, E. D., E. B. LAURIDSEN and H. WELLENDORF (1995): Second evaluation of an international series of teak provenance trials. Danida Forest Seed Centre (Danish Centre for Forest, Landscape and Planning), Denmark, $118 \mathrm{pp}$.

KRISHNAPILLAY, B. (2000): Silviculture and management of teak plantations. Unasylva 51: 14-21.

KUANG, B., S. ZHEN, M. LUO and M. LIN (1996): Evaluation of aggregate genetic value of main characters of provenances of teak. Forest Research 9: 7-14.

Kumaravelu, G. (1993): Teak in India. In: H. Wood (ed.) Teak in Asia, FORSPA Publication No. 4, Bangkok, pp. 27-34.

Madoffe, S. S. and J. A. Maghembe (1988): Performance of teak (Tectona grandis) provenances seventeen years after planting at Longuza, Tanzania. Silvae Genetica 37: 175-178.

MuthuRAmkumar, S. and N. PARThasarathy (2000): Alpha diversity of lianas in a tropical evergreen forest in the Anamalais, Western Ghats, India. Diversity and Distributions 6: $1-14$.

Pandey, D. and C. Brown (2000): Teak: a global overview. Unasylva 51: 3-13.
Pedersen, A. P. (1995): IUFRO Symposium on Innovations in Tropical Tree Seed Technology. Post Symposium Tour Guide, pp. 27-33.

Persson, A. (1971a): Observations from a provenance trial of Tectona grandis Linn. F. at Longuza, Tanga Region. Tanzania Silviculture Res. Note 22. Lushoto. 13 p.

Persson, A. (1971b): Observations from a progeny trial of Tectona grandis Linn. F. at Longuza, Tanga Region. Tanzania Silviculture Res. Note 24. Lushoto. 11 p.

SAS Inst. INC. (1999): SAS OnlineDoc_version eight, SAS Institute Inc., Cary, NC, USA, http://v8doc.sas.com/ sashtml.

SHAPIRO, S. S. and M. B. WILK (1965): An analysis of variance test for normality (complete samples). Biometrika 52, 591-611.

SuHAENDI, H. (1998): Teak improvement in Indonesia. In: Teak for the Future - Proceedings of Second Regional Seminar on Teak. Myanmar 1995. Edited by: MASAKAzU KASHIO and KeVIN White, FAO Regional Office for Asia and the Pacific.

WooD, P. J. (1967): Teak planting in Tanzania. Proc. FAO World Symp. Man-made forests. Document 3: Canberra, A.C.T., pp. $1631-1644$.

\title{
Swiss Stone Pine Provenance Experiment in Romania: II Variation in Growth and Branching Traits to Age 14
}

\author{
By I. BLADA*) and F. Popescu \\ Forest Research and Management Institute, Sos. Stefanesti, 128, Sector 2, Bucharest 11, Romania
}

(Received 10 ${ }^{\text {th }}$ April 2006)

\begin{abstract}
Summary
After the nursery testing, twelve Swiss stone pine (Pinus cembra L.) provenances from the Alps and Carpathian Mountains were planted out at two sites located at high elevation in the Southern and Northern Carpathians. Total height growth $(\mathrm{H})$, annual height growth (h), root collar diameter (RCD), branches per whorl (BW) and survival (SV) were measured and analyzed. Analysis of variance showed highly significant $(\mathrm{p}<0.01 ; \mathrm{p}<0.001)$ differences between provenances for all traits, except survival, suggesting that selection at the provenance level could be possible. Also, over locations analysis revealed significant genotype $\mathrm{x}$ environment interaction, demonstrating that some provenances react differently to environmental conditions and, selection should take this into account. The phenotypic coefficient of variation was moderate for growth and high for number of branches per whorl suggesting that selection within provenance can also be applied.
\end{abstract}

*) Corresponding author: I. BLADA. E-mail: ioan_blada@yahoo.com
Finding of significant and highly significant age-age and trait-trait phenotypic correlations indicated that early and indirect selection in Swiss stone pine species is possible. According to DunCAN's multiple range test the best performing provenances of the two mountain ranges were selected for operational planting and breeding programmes. The results of this study validate that a very slow growing species, such as Swiss stone pine may still possess very high genetic variation in growth rate; consequently, this trait can be improved. Finally, an attempt has been made to develop a seed transfer guidelines for the species by using the pattern of geographic variation as a basis.

Key words: Pinus cembra, Swiss stone pine, provenance trial, genetic variation, growth traits, branching, age-age correlation, early selection, indirect selection.

\section{Introduction}

The Swiss stone pine is a glacial age relict naturally distributed at high elevations in the Alps and Carpathi- 
an Mountains (CRITCHFIELD and LiTTLE, 1966). It occurs mostly in Switzerland, Austria, Northern Italy, southeastern France, Romania, Slovakia, Poland and the Ukraine (SchMidT, 1994). Although Swiss stone pine is considered related to Siberian stone pine, over 1500 miles $(2400 \mathrm{~km})$ presently separate the two species (CRITChField and LitTle, 1966; Mirov, 1967).

In the Alps, Swiss stone pine occurs between $1200 \mathrm{~m}$ and $2500 \mathrm{~m}$ elevation (CONTINI and LAVARELLO, 1982) but it is more frequent between $1500 \mathrm{~m}$ and $2000 \mathrm{~m}$ (HolzLeR, 1975). In the Northern Carpathians the species ranges between $1350 \mathrm{~m}$ and $1880 \mathrm{~m}$ elevation (Gubesh, 1971) while in the Southern Carpathians between $1350 \mathrm{~m}$ and $1986 \mathrm{~m}$ (BELDIE, 1941; TATARANU and Costea, 1952; OARCEA, 1966). Recently, in the Retezat Mountains (Southern Carpathians), Swiss stone pine was naturally found at as high as 2050 m elevation (BLADA, unpublished data).

Swiss stone pine, Norway spruce (Picea abies L.), dwarfed mountain pine (Pinus mugo Turra) and larch (Larix decidua Mill.) are the most important component species of the high elevation forests of the Carpathians. Unfortunately, these mountain forests were partially destroyed by human activities and domestic animal grazing. Swiss stone pine populations were most affected, so that over large areas the species has reduced to scattered trees.

The Bucegi and the Rodnei Mountains of the Southern and Northern Carpathians, respectively, can be regarded as typical examples where the Swiss stone pine populations are at the edge of extinction. Thus, their restoration and protection through a conservation programme are strongly recommended.

Though Swiss stone pine is very slow growing pine, it is important to the Carpathians for various reasons, such as ecological (HoLzER, 1972, 1975), silvicultural (BlADA, 1996), genetically (BINGHAM, 1972; HolzER, 1975; HoFF et al., 1980; BLADA, 1987, 1990, 1994), landscaping (BLADA, 1996) and manufacturing goods (CONTINI and LAVARELLO, 1982).

Research work carried out to date on Swiss stone pine intra-specific variability revealed that phenotypic variability in crown shape and stem form was noticed (RIKLI, 1909; HoLzER, 1975). In two trials with half-sib progenies, there was obtained a good correlation between height growth and the elevation of the seed source (HoLzER, 1975). Very high variation in both number and weight of seeds per cone was found within each investigated population, but variation in 100 seed weight was only moderate (BLADA and PoPESCU, 1992). In the nursery test, highly significant differences were found among provenances for growth traits (BLADA, 1987, 1997). An analysis of a diallel test confirmed the high genetic variation in growth traits even though cembra pine is a slow growing species (BLADA, 1999).

The nursery test results of the 12 geographic seed sources of Swiss stone pine were previously evaluated for growth traits (BLADA, 1977). The present study reports the field performances of Swiss stone pine provenances in survival, growth and branching in two provenance trials including the same 12 geographic seed sources. The results of the study were further evaluated to develop a seed transfer guidelines for further reforestation programmes with species in the Carpathians.

\section{Materials and Methods}

\section{Provenances}

The experiment consisted of 12 geographic origins or provenances seven of which originate in the Carpathians and five in the Alps Mountains (Table 1). The provenances covered a range of natural populations, distributed across $4^{\circ} 36^{\prime}$ in latitude (between $45^{\circ} 12^{\prime} \mathrm{N}$ and $49^{\circ}$ $48^{\prime} \mathrm{N}$ ) and $20^{\circ} 29^{\prime}$ in longitude (between $4^{\circ} 48^{\prime} \mathrm{E}$ and $25^{\circ}$ $17^{\prime} \mathrm{E}$ ) and from $1520 \mathrm{~m}$ to $2175 \mathrm{~m}$ elevation. Each provenance represented one stand and comprised of bulked seedlots collected from 10 to 20 open pollinated trees per population. The trees from which seed was collected were at least $50 \mathrm{~m}$ distance away from each other.

Table 1. - Cembra pine provenances in the Carpathian field trials.

\begin{tabular}{|c|l|c|c|c|}
\hline Code & \multicolumn{1}{|c|}{ Provenance } & $\begin{array}{c}\text { Lat. } \\
\left({ }^{\circ} \mathrm{N}\right)\end{array}$ & $\begin{array}{c}\text { Long. } \\
\left({ }^{\circ} \mathrm{E}\right)\end{array}$ & $\begin{array}{c}\text { Alt. } \\
(\mathrm{m})\end{array}$ \\
\hline 1 & Gemenele (SC) & $45^{\circ} 22^{\prime}$ & $22^{\circ} 50^{\prime}$ & 1.780 \\
2 & Pietrele (SC) & $45^{\circ} 23^{\prime}$, & $22^{\circ} 52^{\prime}$ & 1.760 \\
3 & Stana de Rau (SC) & $45^{\circ} 21^{\prime}$, & $23^{\circ} 03^{\prime}$ & 1.680 \\
4 & Calimani (NC) & $47^{\circ} 07^{\prime}$, & $25^{\circ} 17^{\prime}$, & 1.650 \\
5 & Valea Lalei (NC) & $47^{\circ} 33^{\prime}$, & $25^{\circ} 05^{\prime}$, & 1.520 \\
6 & Pietrosul (NC) & $47^{\circ} 37^{\prime}$ & $24^{\circ} 40^{\prime}$ & 1.770 \\
7 & Papusa-Iezer, (SC) & $45^{\circ} 29^{\prime}$ & $25^{\circ} 05^{\prime}$ & 1.480 \\
8 & Grachen Wallis (SA) & $45^{\circ} 12^{\prime}$ & $7^{\circ} 52^{\prime}$, & 2.140 \\
9 & Bluhnbach (AA) & $47^{\circ} 27^{\prime}$ & $13^{\circ} 06^{\prime}$, & 1.575 \\
10 & Imst-Roppen (A.A.) & $47^{\circ} 10^{\prime}$ & $10^{\circ} 51^{\prime}$, & 1.950 \\
11 & Sirnitz-Gilendorfer (AA) & $46^{\circ} 55^{\prime}$ & $13^{\circ} 56^{\prime}$ & 1.740 \\
12 & Bois de Ayes (FA) & $49^{\circ} 48^{\prime}$ & $4^{\circ} 48^{\prime}$ & 2.175 \\
\hline
\end{tabular}

$\mathrm{SC}, \mathrm{NC}=$ Southern and Northern Carpathians, respectively. $\mathrm{SA}, \mathrm{AA}, \mathrm{FA}=$ Swiss, Austrian and French Alps, respectively.

\section{Sites and experimental layout}

After the nursery test (BLADA, 1997), two field trials were laid out in autumn of 1997 years in two sites. One site was located in the Surianu Mountain (Cugir Forest District/Southern Carpathians) at $45^{\circ} 37^{\prime} \mathrm{N}$ latitude, $23^{\circ} 32^{\prime} \mathrm{E}$ longitude and $1550 \mathrm{~m}$ elevation. The other site was placed in the Inau Mountain (Carlibaba Forest District/Northern Carpathians) at $47^{\circ} 33^{\prime} \mathrm{N}$ latitude and $24^{\circ} 55^{\prime} \mathrm{E}$ longitude. In each site, the trial was layout according to a complete randomized block design with 12 provenances, three blocks and 30-trees rectangle plot per block, spaced $2.5 \times 2.5 \mathrm{~m}$.

\section{Assessments and statistical analysis}

Five traits in the field test were recorded at successive ages (Table 2), such as: height growth between age 10 and 14 , root collar diameter between age 10 and 12 ,

Table 2. - Measured traits.

\begin{tabular}{|l|c|c|}
\hline \multicolumn{1}{|c|}{ Trait } & Units & Symbol \\
\hline Total height growth & $\mathrm{cm}$ & H.3...H.14 \\
Annual height growth & $\mathrm{cm}$ & h.4...h.14 \\
Root collar diameter & $\mathrm{mm}$ & RCD.4...RCD.12 \\
Branches per whorl & No. & BW.12...BW.14 \\
Survival & $\%$ & SV.14 \\
\hline
\end{tabular}


number of branches per whorl between 12 and 14 and survival at 14 years. The total height growth and number of branches per whorl were the two traits of major importance for Swiss stone pine. The measurements were made on samples of 20 trees of each provenance from each replication.

For the analysis of field data, plot means of 12 provenances grown at both sites were used. Data were subjected to a variance analysis by location and then over locations, as well, with plot means as the analysis units. Statistical model was taken from van BUIJTENEN, and YEISER (1989) adapted to the provenance experiment, as follows

$$
\mathrm{Y}_{\mathrm{ijk}}=\mu+\mathrm{B}_{\mathrm{i}}+\mathrm{P}_{\mathrm{j}}+\mathrm{BP}_{\mathrm{ij}}+\varepsilon_{\mathrm{ijk}}
$$

where: $Y_{\mathrm{ijk}}=$ the $\mathrm{kth}$ tree of the jth provenance in the kth block; $\mu=$ the trial mean; $B_{i}=$ the ith block; $P_{j}=$ the jth provenance; $\mathrm{BP}=$ the the interaction of the ith block and jth provenance; $\varepsilon_{\mathrm{ijk}}=$ the random error.

At age 14, the Duncan Multiple Range Test (DuncAN, 1955) was used to separate the provenances into homogeneous groups and to establish the level of significance of each provenance compared to the trial mean at each location. To compare the results, data from age six for total and annual height growth were included in the DUNCAN test.

The least significant difference (LSD) to be applied to the DunCAN test was calculated by the formula given by CeApoiu, (1968)

$$
\mathrm{LSD}=\sqrt{ }\left(2 \mathrm{MS}_{\mathrm{E}}\right) / \mathrm{R}
$$

where: $\mathrm{MS}_{\mathrm{E}}=$ error mean square; $\mathrm{R}=$ number of replications.

The age-age and trait-trait phenotypic correlations were estimated for both nursery and field test even though the nursery data were not included in the present variance analysis. Also, correlations between height growth and number of branches per whorl at age 14 from seed, on one side, and geographic coordinates (including the ecophysiological latitude), on the other side were calculated.

The ecophysiological latitude was estimated using the formula (WIERSMA, 1962).

$$
\mathrm{Le}=\mathrm{L}+\mathrm{A} / 100
$$

\where: Le = ecophysiological latitude; $\mathrm{L}$ and $\mathrm{A}=$ latitude and altitude, respectively. Latitude is thus corrected for altitude in such a way that $100 \mathrm{~m}$ difference in altitude is considered to equal a difference of one degree in latitude. The ecophysiological latitude can be thought of as latitude reduced to sea level and is considered to better define the relationship between growth and geographical location than either latitude or altitude alone. Finally, a regression between total height growth and number of branches per whorl was calculated.

Note: the letters $(\mathrm{S}),(\mathrm{N})$ and $(\mathrm{S} / \mathrm{N})$ that will be used subsequently refers to southern and northern trials or

\begin{tabular}{|c|c|c|c|c|c|c|c|c|c|}
\hline \multirow{2}{*}{$\begin{array}{c}\text { Source } \\
\text { variation }\end{array}$} & \multicolumn{9}{|c|}{ Traits / Mean squares } \\
\hline & $\mathrm{DF}$ & H.10 & H.11 & H.12 & H.13 & H.14 & h.10 & h.11 & h.12 \\
\hline \multicolumn{10}{|c|}{ The Southern Carpathians trial } \\
\hline Replic. & 2 & 27.60 & 1.28 & 39.52 & 18.28 & 55.83 & 10.36 & 1.27 & 13.35 \\
\hline Prov. & 11 & $242.23 * * *$ & $413.28 * * *$ & $745.01 * * *$ & $661.86^{* * *}$ & $1368.92 * * *$ & $22.39 * * *$ & $19.28 * * *$ & $24.41 * * *$ \\
\hline Error & 22 & 11.82 & 37.71 & 33.52 & 61.80 & 71.36 & 2.19 & 4.01 & 4.40 \\
\hline Trait mean & & 48.9 & 65.1 & 87.9 & 107.9 & 139.0 & 14.4 & 16.4 & 22.8 \\
\hline & & & & & & & & & \\
\hline Source & $\mathrm{DF}$ & H.10 & H.11 & H.12 & H.13 & H.14 & h.10 & h.11 & h.12 \\
\hline \multicolumn{10}{|c|}{ The Northern Carpathians trial } \\
\hline Replic. & 2 & 66.72 & 36.31 & 39.37 & 189.31 & 94.85 & 2.37 & 2.01 & 0.12 \\
\hline Prov. & 11 & $157.94 * * *$ & $211.30^{* * *}$ & $701.82 * * *$ & $780.20 * * *$ & $906.39 * * *$ & $3.96^{* *}$ & $15.09 * * *$ & $21.61 * * *$ \\
\hline Error & 22 & 15.16 & 26.88 & 27.47 & 42.63 & 64.59 & 1.10 & 2.49 & 2.57 \\
\hline Trait mean & & 41.0 & 56.1 & 73.7 & 97.0 & 126.9 & 10.6 & 16.6 & 19.7 \\
\hline & & & & & & & & & \\
\hline Source & DF & h.13 & h.14 & RCD.10 & RCD.12 & BW.12 & BW.13 & BW.14 & SV. 14 \\
\hline \multicolumn{10}{|c|}{ The Southern Carpathians trial (Continued) } \\
\hline Replic. & 2 & 1.15 & 3.28 & 9.43 & 1.60 & 3.21 & 3.47 & 0.66 & 12.45 \\
\hline Prov. & 11 & $30.26^{* * *}$ & $44.37 * * *$ & $7.15^{* * *}$ & $37.76^{* * *}$ & $8.63 * * *$ & $2.99 * * *$ & $4.73 * * *$ & 45.90 \\
\hline Error & 22 & 3.63 & 1.69 & 1.29 & 2.91 & 0.94 & 0.46 & 0.66 & 21.94 \\
\hline Trait mean & & 28.8 & 27.8 & 22.1 & 35.9 & 5.7 & 6.9 & 8.9 & 99.3 \\
\hline & DF & h 13 & h 14 & RCD 10 & RCD 12 & NRW 12 & NBW 13 & NRW 14 & SV 14 \\
\hline \multicolumn{10}{|c|}{ The Northern Carpathians trial (Continued) } \\
\hline Replic. & 2 & 7.22 & 5.67 & 27.53 & 13.37 & 3.91 & 1.99 & 0.80 & 13.01 \\
\hline Prov. & 11 & $40.41 * * *$ & $22.79 * * *$ & $17.60^{* * *}$ & $76.63 * * *$ & $5.12 * * *$ & $6.11 * * *$ & $2.20 * * *$ & 34.96 \\
\hline Error & 22 & 2.06 & 3.23 & 1.64 & 8.92 & 0.64 & 0.34 & 0.35 & 18.62 \\
\hline Trait mean & & 24.9 & 24.9 & 19.5 & 30.6 & 6.6 & 6.0 & 8.2 & 99.8 \\
\hline
\end{tabular}
both.

Table 3. - Analysis of variance of cembra provenances at the field stage, by location.

$* \mathrm{p}<0.05 ; * * \mathrm{p}<0.01 ; * * * \mathrm{p}<0.001 ; \mathrm{H}, \mathrm{h}, \mathrm{RCD} \& \mathrm{BW}=$ total and annual height growth and root collar diameter and number of branches per whorl, respectively, at successive ages; SV.14 = survival at age 14 


\section{Results and Discussions}

\section{Variation at the Southern Carpathians trial (S)}

Variation in total height growth $(\mathrm{S})$

Over the entire field testing period, variance analysis results showed highly significant $(\mathrm{p}<0.001)$ genetic differences between provenances in total height growth (Table 3). Such genetic differences suggest that:

- although the species is very slow growing; it possesses considerable genetic variation in growth rate at provenance level;

- based on the within species variation, selection of faster growing provenances for reforestation and for operational tree improvement will be effective; a faster growing provenance planted at sub-alpine zones will colonize the area much faster than a slow growing one; the faster colonization of the steep slopes will be most efficient for site stabilization.

The across locations analysis indicated significant $(\mathrm{p}<0.05)$ or highly significant $(\mathrm{p}<0.01 ; \mathrm{p}<0.001)$ site effects on total height growth. All the interactions between provenance and site were highly significant $(\mathrm{p}<0.001)$ for growth (Table 4), suggesting that several provenances would exhibit relatively fast growth in one environment but slower growth in another. Therefore, provenance selection should be done according to these local performances. It was presumed that site climate and not site productivity was the main cause of the interaction.

The mean total height growth of provenances at age 14 ranged from $100.7 \mathrm{~cm}$ for the Pietrosul source to $165.3 \mathrm{~cm}$ for Pietrele a difference of $64.2 \%$ indicating a high range of variation and excellent possibilities for effective selection. When compared to the plantation mean, the DuncAN Multiple Range Test showed that the Pietrele, Calimani, Stana de Rau and Gemenele provenances from Carpathians were significantly $(\mathrm{p}<0.05)$ or highly significantly $(\mathrm{p}<0.01 ; \mathrm{p}<0.001)$ better in total height growth than all other provenances (Table 5 column 7). Quantitatively, they surpassed the plantation mean by $18.9 \%, 18.5 \%, 12.0 \%$ and $10.6 \%$, respectively (Fig. 1A) and consequently, if height growth is to be taken into account, these four provenances should be used for reforestation in the Southern Carpathians and in advanced-generation improvement. In contrast, the Bois des Ayes, Grachen Wallis and Pietrosul held the last three places in rank (Table 5, column 7) and their performances were significantly $(\mathrm{p}<0.05)$ or highly significantly $(\mathrm{p}<0.001)$ below the plantation mean by $12.1 \%, 23.6 \%$ and $27.6 \%$, respectively (Fig. $1 A$ ). The

Table 4. - Analysis of variance of cembra pine provenances field trials combined over locations.

\begin{tabular}{|c|c|c|c|c|c|c|c|c|c|}
\hline \multirow{2}{*}{$\begin{array}{c}\text { Source of } \\
\text { variation }\end{array}$} & \multirow[b]{2}{*}{ DF } & \multicolumn{8}{|c|}{ Traits / Mean squares } \\
\hline & & H.10 & H.11 & H.12 & H.13 & H.14 & h.10 & h.11 & h.12 \\
\hline Replic. & 4 & 47.16 & 18.80 & 39.44 & 103.79 & 75.34 & 6.37 & 1.64 & 6.74 \\
\hline Prov. (P) & 11 & $346.25 * *$ & $558.86 * * *$ & $1228.15 * *$ & $1182.03^{*}$ & $1969.14 * *$ & 15.40 & $31.42 * * *$ & $38.87 * *$ \\
\hline Locations (L) & 1 & $1111.31 * * *$ & $1461.35^{* * *}$ & $4395.51 * *$ & $2136.73 * *$ & $2615.81 *$ & $253.26 * * *$ & 1.27 & $177.96^{* * *}$ \\
\hline$P \times L$ & 11 & $59.93 * * *$ & $65.72 * * *$ & $218.67 * * *$ & $280.03 * * *$ & $306.17 * * *$ & $10.95 * * *$ & 2.95 & $7.15^{*}$ \\
\hline Error & 44 & 13.49 & 33.80 & 30.49 & 52.21 & 67.97 & 1.65 & 3.25 & 3.48 \\
\hline \multirow{2}{*}{$\begin{array}{l}\text { Source of } \\
\text { variation }\end{array}$} & \multirow[b]{2}{*}{ DF } & \multicolumn{8}{|c|}{ Traits / Mean squares } \\
\hline & & h.13 & h.14 & RCD.10 & RCD.12 & BW.12 & BW.13 & BW.14 & SV.14 \\
\hline Replic. & 4 & 4.18 & 4.47 & 18.48 & 7.48 & 3.56 & 2.73 & 0.73 & 12.73 \\
\hline Prov. (P) & 11 & $52.49^{*}$ & $57.12 * *$ & $18.49 *$ & 57.37 & $12.72 * * *$ & 3.22 & $5.19 *$ & 45.65 \\
\hline Locations (L) & 1 & $272.09 * *$ & $151.38 * *$ & $122.88^{* * *}$ & $517.16^{*}$ & 4.44 & 14.79 & 8.42 & 81.49 \\
\hline $\mathrm{P} \times \mathrm{L}$ & 11 & $18.17^{* * *}$ & $10.04 * * *$ & $6.26 * * *$ & $57.03 * * *$ & 1.03 & $5.88 * * *$ & $1.74 * *$ & 35.21 \\
\hline Error & 44 & 2.84 & 2.46 & 1.46 & 5.91 & 0.79 & 0.40 & 0.5 & 20.28 \\
\hline
\end{tabular}

$* \mathrm{p}<0.05 ; * * \mathrm{p}<0.01 ; * * * \mathrm{p}<0.001$

Table 5. - Provenances distribution on homogeneous groups according to DunCAN Test $(\mathrm{p}<0.01)$ for the Southern Carpathians trial.

\begin{tabular}{|c|c|c|c|c|c|c|c|c|c|c|c|c|c|c|}
\hline \multicolumn{3}{|c|}{ H.6 } & \multicolumn{3}{|c|}{ h. 6} & \multicolumn{3}{|c|}{ H.14 } & \multicolumn{3}{|c|}{ h. 14} & \multicolumn{3}{|c|}{ BW.14 } \\
\hline Prov & $\begin{array}{l}\text { Mean } \\
(\mathrm{cm})\end{array}$ & $\begin{array}{c}\text { DUNCAN } \\
\text { Test }\end{array}$ & Prov & $\begin{array}{l}\text { Mean } \\
(\mathrm{cm})\end{array}$ & $\begin{array}{c}\text { DUNCAN } \\
\text { Test }\end{array}$ & Prov & $\begin{array}{l}\text { Mean } \\
(\mathrm{cm})\end{array}$ & $\begin{array}{c}\text { DUNCAN } \\
\text { Test }\end{array}$ & Prov & $\begin{array}{l}\text { Mean } \\
(\mathrm{cm})\end{array}$ & $\begin{array}{c}\text { DUNCAN } \\
\text { Test }\end{array}$ & Prov & $\begin{array}{l}\text { Mean } \\
\text { (No.) }\end{array}$ & $\begin{array}{c}\text { DUNCAN } \\
\text { Test }\end{array}$ \\
\hline 1 & 2 & 3 & 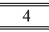 & 5 & 6 & 7 & 8 & 9 & 10 & 11 & 12 & 13 & 14 & 15 \\
\hline 2 & $27.5^{* * * *}$ & & 2 & $12.3^{* * *}$ & & 2 & $165.3^{* * *}$ & & 2 & $32.8 * * *$ & & 11 & $11.1^{* *}$ & I \\
\hline 9 & $22.9^{* * * *}$ & 1 & 9 & $9.7 * * *$ & & 4 & $164.8^{* *}$ & & 4 & $31.7^{* *}$ & & 7 & 9.8 & \\
\hline 1 & $21.7 * *$ & & 1 & $9.5^{* * *}$ & & 3 & $155.7^{*}$ & & 3 & $31.2 * *$ & & 2 & 9.8 & \\
\hline 4 & $20.8^{* *}$ & & 4 & $8.7^{* *}$ & & 1 & $153.8^{*}$ & & 11 & $30.3^{*}$ & & 9 & 9.5 & \\
\hline 10 & 17.0 & & 10 & 6.6 & 1 & 9 & 153.1 & & 9 & 29.4 & 1 & 3 & 9.4 & \\
\hline 3 & 15.9 & & 3 & 6.3 & & 11 & 142.0 & & 10 & 28.6 & & 4 & 9.3 & \\
\hline 7 & 14.9 & & 7 & 6,2 & & 10 & 140,3 & 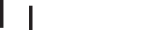 & 1 & 28,1 & & 1 & 8,9 & \\
\hline 5 & $13.4^{\circ 0}$ & & 5 & $5.2^{\circ}$ & & 7 & 136.5 & & 7 & 27.6 & & 10 & 8.5 & \\
\hline 8 & $13.3^{\circ 0}$ & & 12 & $4.7^{\circ 0}$ & & 5 & 127.6 & I & 5 & 26.9 & & 5 & 8.5 & \\
\hline 12 & $12.6^{\circ 00}$ & | & 11 & $3.8^{000}$ & 1 & 12 & $122.2^{\circ}$ & 1 & 12 & $25.2^{\circ}$ & & 12 & 8.0 & \\
\hline 11 & $10.8^{\circ 00}$ & & 8 & $3.8^{000}$ & & 8 & $106.3^{000}$ & 1 & 8 & $21.8^{000}$ & & 6 & 7.8 & \\
\hline 6 & $10.1^{000}$ & & 6 & $3.2^{000}$ & & 6 & $100.7^{000}$ & 1 & 6 & $20.2^{000}$ & & 8 & $6.1^{000}$ & I \\
\hline $\mathrm{X}$ & 16.8 & & $\mathrm{X}$ & 6.7 & & $\mathrm{X}$ & 139.0 & & $\mathrm{X}$ & 27.8 & & $\mathrm{X}$ & 8.9 & \\
\hline$\angle S D p<0.05$ & 2.3 & & & 1.3 & & & 14.3 & & & 2.2 & & & 1.4 & \\
\hline$\angle S D p<0.01$ & 3.1 & & & 1.7 & & & 19.4 & & & 3.6 & & & 1.9 & \\
\hline$\angle S D p<0.001$ & 4.1 & & & 2.2 & & & 26.2 & & & 4.6 & & & 2.5 & \\
\hline
\end{tabular}

$* \mathrm{p}<0.05 ; * * \mathrm{p}<0.01 ; * * * \mathrm{p}<0.001$ (for above trial mean differences); ${ }^{\circ} \mathrm{p}<0.05 ;{ }^{\circ} \mathrm{p}<0.01 ;{ }^{\circ 00} \mathrm{p}<0.001$ (for below trial mean differences); $\mathrm{X}=$ trait mean. 


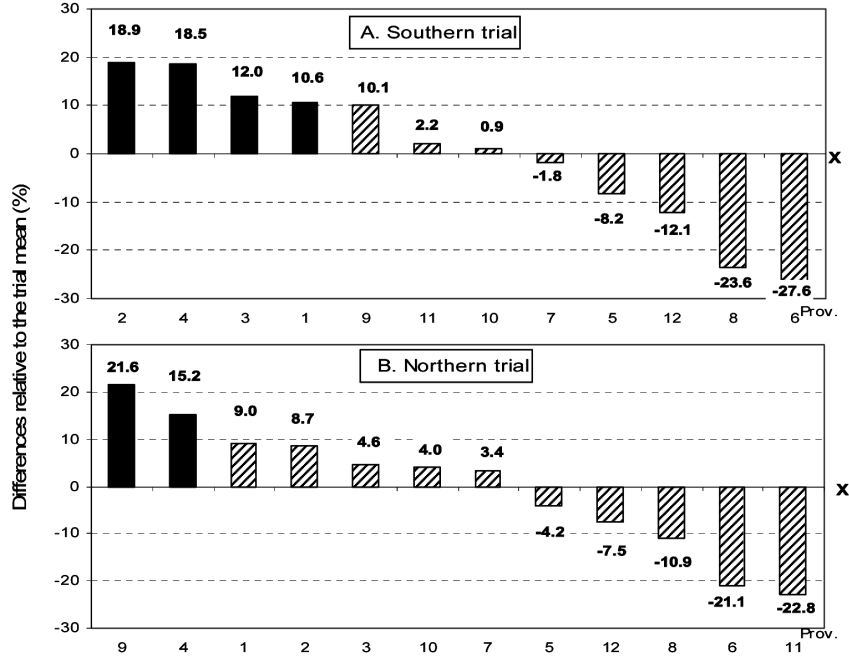

Figure 1. - Performance (\%) of the cembra pine provenances in total height growth at age 14 , relative to the trial mean.

remaining provenances formed groups which were not significantly different from each other. Of particular interest was the Calimani source, originating in the Northern Carpathians, which in the Southern trial exhibited a growth rate similar to the best local source, e. g. Pietrele, suggesting an insignificant provenance $x$ environment interaction.

Comparison of rankings of mean total height growth in the nursery test at age six and that in the field test at age 14 (Table 5 columns 1 and 7 ) revealed that:

- the Pietrele, Gemenele and Calimani provenances held their statistically significant top positions at both age six and 14 while the Bluhnbach source dropped from significant second to non-significant fifth position in the rank; thus, the above three including Stana de Rau provenances are recommended for plantations in the Southern Carpathians;

- the Valea Lalei, Grachen Wallis, Bois-des-Ayes, Sirnitz-Gilendorfer and Pietrosul sources held the bottom part of the rank at both age six and 14, except the Sirnitz-Gilendorfer source, which jumped in ranking from second last at age six to sixth position at age 14; all of these should not be taken into account for reforestation.

- in general, when the total height growth and annual height growth rankings from the nursery test were compared to those from the field test at age 14, a generally similar pattern of rankings occurred, so that positive age-age correlation can be expected.

- with the exception of the Bluhnbach source, all provenances originating in the Alps Mountains exhibited significantly less total height growth than the Carpathian sources, so they will not be included in the operational planting programs.

\section{Variation in annual height growth $(\mathrm{S})$}

Highly significant differences in annual height growth occurred among provenances $(p<0.001)$, a trend that was set in field tests (Table 3). When the rankings were compared (Table 5, columns 4 and 10), the Pietrele and Calimani provenances were statistically highly significant at the top two positions in rank at both age six and
14, while Bluhnbach and Gemenele dropped in the rank to the fifth and seventh positions, respectively. The Boisdes-Ayes, Grachen Wallis and Pietrosul provenances occupied the bottom three ranks at both age six and 14, while the Sirnitz-Gilendorfer provenance jumped in ranking from tenth position at age six to fourth position at age 14. A consistent pattern was apparent in the rankings for both total and annual height growth at age 14 (Table 5, columns 7 and 10) but only partially consistent with rankings from the age six nursery test (Table 5 , columns 1 and 4).

\section{Variation in number of branches per whorl (S)}

The number of branches per whorl was recorded at 12 , 13, and 14 years of age. At all three ages the differences among provenance were highly significant $(p<0.001)$ (Table 3). Owing to this variation, selection of provenances with individuals having a larger number of branches per whorl can be done. A larger number of branches per whorl/tree give rise to a denser crown which has a higher capacity for snow and water retention. Such an increase in precipitation retention may significantly contribute to preventing avalanche initiation, soil erosion and flooding downstream.

Results of across sites analysis of variance indicated no significant site effects on number of branches per whorl. But, provenance $\mathrm{x}$ site interaction was highly significant $(\mathrm{p}<0.01 ; \mathrm{p}<0.001)$ suggesting that several provenances could exhibit high numbers of branches per whorl at one environment and lower numbers at the other (Table 4).

The mean number of branches per whorl at age 14 ranged from 6.1 for Grachen Wallis to 11.1 for SirnitzGilendorfer, a difference of $82 \%$, suggesting a high range of variation and excellent possibilities of selection. The Duncan Multiple Range Test showed that, compared to the plantation mean, the Sirnitz-Gilendorfer provenance was highly significantly $(p<0.01)$ better in number of branches per whorl than all other provenances (Table 5, column 13). Quantitatively, it sur-

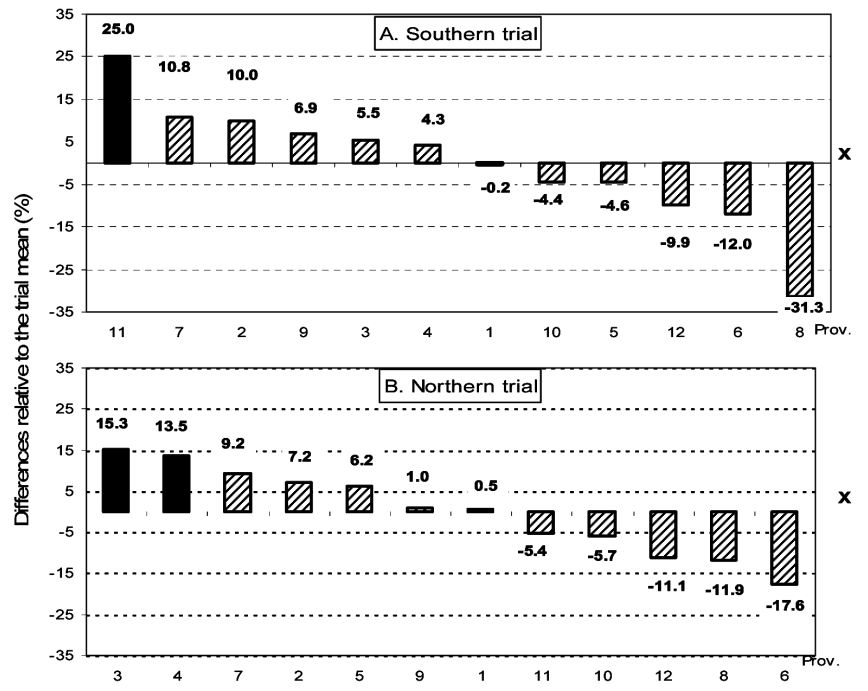

Figure 2. - Performance (\%) of the cembra pine provenances in number of branches per whorl at age 14 , relative to the trial mean. 
passed the plantation mean by $25.0 \%$. In contrast, the Grachen Wallis provenance held the last place in rank and its performances was negatively highly significantly $(\mathrm{p}<0.001)$ lower than the plantation mean by $31.3 \%$ (Fig. 2A). Therefore, if the objective is to improve the number of branches per whorl, the Sirnitz-Gilendorfer provenance should be selected and used for operational tree improvement and for reforestation in the Southern Carpathians. The remaining provenances formed groups which were not significantly different from each other.

\section{Phenotypic coefficients of variation (S)}

Low to moderate within provenance variation was found in total and annual height growth but high variation was found in number of branches per whorl. At the Southern trial, the coefficients of variation ranged between $6.9 \%$ and $15 \%$ in total height growth, $12.9 \%$ and $24.3 \%$ in annual height growth and $12.7 \%$ and $31.6 \%$ in total number of branches per whorl, i. e. a mean variation of $12.5 \%, 15.4 \%$ and $24.0 \%$, respectively (Table 7). According to these figures, genetic selection can be effectively applied at both provenance and tree within provenance level.

\section{Phenotypic age-age correlations (S)}

At the Southern test, correlations between variables at different ages indicated a very clear pattern (Table 8). Age-age phenotypic correlations for height growth were significant $(\mathrm{p}<0.05)$ or highly significant $(\mathrm{p}<0.01$; $\mathrm{p}<0.001)$ in most cases. This indicates that early selection for height growth may be efficient. Generally, the age-age correlations for total height were higher than those for root collar diameter and especially for number of branches per whorl. The age-age correlations between annual height growths at age four and successive estimates of the same trait were generally not significant. However, age-age correlations for age six and older with successive estimates were generally highly correlated and significant. Age-age correlations for number of branches per whorl were significant $(p<0.05)$ only between age 13 and 14 . These results clearly indicate that early selection for previously mentioned traits, except for number of branches per whorl may be efficient. In other words, in case of the cembra pine, selec- tion for growth traits can be done after a few years of field testing.

\section{Phenotypic trait-trait correlations (S)}

The trait-trait correlations are presented in table 8. Trait-trait phenotypic correlations between total height growth and successive annual height growth and root collar diameter and number of branches per whorl were significant $(\mathrm{p}<0.05)$ or highly significant $(\mathrm{p}<0.01$; $\mathrm{p}<0.001$ ) in all but seven cases. Correlations between total height growth and number of branches per whorl were less well correlated than traits previously mentioned. However, trait-trait correlations between total height growth at ages 13 and 14 and successive number of branches per whorl at ages 12 and 14 were significant $(\mathrm{p}<0.05)$ or highly significant $(\mathrm{p}<0.01 ; \mathrm{p}<0.001)$. In many cases, a lack of significance was found between annual height growth and successive root collar diameter and number of branches per whorl. Also, in most cases, the root collar diameter was not significantly correlated with number of branches per whorl. Consequently, with minor exceptions, the results showed that indirect selection may be applied for the two major traits, total height growth and number of branches per whorl.

\section{Variation at the Northern Carpathians trial (N)}

Variation in total height growth $(\mathrm{N})$

Highly significant $(\mathrm{p}<0.01)(\mathrm{p}<0.001)$ genetic differences occurred between provenances in total height growth (Table 3) suggesting, as did the Southern test, that selection of some valuable sources of practical importance for reforestation and for operational tree improvement programmes can be done.

The provenance mean total height growth at age 14 ranged from $98.0 \mathrm{~cm}$ for Sirnitz-Gilendorfer to $154.4 \mathrm{~cm}$ for Bluhnbach, a difference of $57.6 \%$. This range of variation is almost as high as that observed at the Southern Carpathian trial. The DuncAN Test showed that, compared to the plantation mean, the Bluhnbach and Calimani provenances were positively highly significantly $(\mathrm{p}<0.01 ; \mathrm{p}<0.001)$ better in total height growth than all other provenances (Table 6, column 7). Quantitatively, they surpassed the plantation mean by $21.6 \%$ and

Table 6. - Provenances distribution on homogeneous groups according to DuncAN Test $(\mathrm{p}<0.01)$ for the Northern Carpathians trial.

\begin{tabular}{|c|c|c|c|c|c|c|c|c|c|c|c|c|c|c|}
\hline \multicolumn{3}{|c|}{ H.6 } & \multicolumn{3}{|c|}{ h. 6} & \multicolumn{3}{|r|}{ H.14 } & \multicolumn{3}{|c|}{ h.14 } & \multicolumn{3}{|c|}{ BW.14 } \\
\hline Prov & $\begin{array}{l}\text { Mean } \\
(\mathrm{cm})\end{array}$ & $\begin{array}{c}\text { DUNCAN } \\
\text { Test }\end{array}$ & Prov & $\begin{array}{l}\text { Mean } \\
(\mathrm{cm})\end{array}$ & $\begin{array}{c}\text { DUNCAN } \\
\text { Test }\end{array}$ & Prov & $\begin{array}{l}\text { Mean } \\
(\mathrm{cm})\end{array}$ & $\begin{array}{c}\text { DUNCAN } \\
\text { Test }\end{array}$ & Prov & $\begin{array}{l}\text { Mean } \\
(\mathrm{cm})\end{array}$ & $\begin{array}{c}\text { DUNCAN } \\
\text { Test }\end{array}$ & Prov & $\begin{array}{l}\text { Mean } \\
\text { (No.) }\end{array}$ & $\begin{array}{c}\text { DUNCAN } \\
\text { Test }\end{array}$ \\
\hline 1 & 2 & 3 & 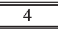 & 5 & 6 & 7 & 8 & 9 & 10 & 11 & 12 & 13 & 14 & 15 \\
\hline 2 & $27.5^{* * * *}$ & I & 2 & $12.3^{* * *}$ & & 9 & $154.4^{* * *}$ & I & 2 & $28.3^{*}$ & I & 3 & $9.4 *$ & | \\
\hline 9 & $22.9^{* * *}$ & 1 & 9 & $9.7 * * *$ & & 4 & $146.2^{* *}$ & 1 & 4 & $28.1^{*}$ & & 4 & $9.3^{*}$ & \\
\hline 1 & $21.7 * *$ & & 1 & $9.5 * * *$ & & 1 & 138.4 & & 9 & 27.8 & & 7 & 9.0 & 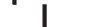 \\
\hline 4 & $20.8^{* *}$ & & 4 & $8.7 * *$ & 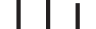 & 2 & 138.0 & & 10 & 26.2 & I & 2 & 8.8 & \\
\hline 10 & 17.0 & & 10 & 6.6 & & 3 & 132.7 & & 1 & 25.5 & & 5 & 8.7 & \\
\hline 3 & 15.9 & & 3 & 6.3 & & 10 & 132.0 & & 3 & 25.1 & & 9 & 8.3 & \\
\hline 7 & 14.9 & & 7 & 6.2 & & 7 & 131.3 & & 5 & 24.7 & & 1 & 8.2 & \\
\hline 5 & $13.4^{\circ 0}$ & & 5 & $5.2^{\circ}$ & & 5 & 121.7 & I & 7 & 24.4 & & 11 & 7.8 & \\
\hline 8 & $13.3^{\circ \circ}$ & & 12 & $4.7^{\circ 0}$ & | & 12 & 117.5 & | & 12 & 24.1 & & 10 & 7.7 & \\
\hline 12 & $12.6^{000}$ & & 11 & $3.8^{\circ 00}$ & & 8 & $113.1^{\circ}$ & I & 8 & 24.1 & & 12 & 7.3 & \\
\hline 11 & $10.8^{000}$ & & 8 & $3.8^{\circ 00}$ & & 6 & $101.1^{000}$ & & 11 & 22.3 & & 8 & 7.2 & \\
\hline 6 & $10.1^{000}$ & & 6 & $3.2^{000}$ & & 11 & $98.0^{\circ 00}$ & & 6 & $18.4^{\circ 00}$ & I & 6 & $6.8^{\circ}$ & | \\
\hline $\mathrm{X}$ & 16.8 & & $\mathrm{X}$ & 6.7 & & $\mathrm{X}$ & 127.0 & & $\mathrm{X}$ & 24.9 & & $\mathrm{X}$ & 8.2 & \\
\hline$\angle S D p<0.05$ & 2.3 & & & 1.3 & & & 13.6 & & & 3.0 & & & 1.0 & \\
\hline$\angle S D p<0.01$ & 3.1 & & & 1.7 & & & 18.5 & & & 4.1 & & & 1.4 & \\
\hline$\angle S D p<0.001$ & 4.1 & & & 2.2 & & & 24.9 & & & 5.6 & & & 1.8 & \\
\hline
\end{tabular}

$* \mathrm{p}<0.05 ; * * \mathrm{p}<0.01 ; * * * \mathrm{p}<0.001$ (for above trial mean differences); ${ }^{\circ} \mathrm{p}<0.05 ;{ }^{\circ} \mathrm{p}<0.01 ;{ }^{\circ}{ }^{\circ 0} \mathrm{p}<0.001$ (for below trial mean differences); $\mathrm{X}=$ trait mean. 
$15.2 \%$, respectively (Fig. $1 B$ ). In contrast, the Grachen Wallis, Pietrosul and Sirnitz-Gilendorfer provenances held the last three positions in rank (Table 6, column 7) and their performances were highly significantly $(\mathrm{p}<0.01)$ below the plantation mean by $10.9 \%, 21.1 \%$ and $22.8 \%$, respectively (Fig. 1B). Surprisingly, at the Southern plantation the Sirnitz-Gilendorfer provenance ranked sixth while at the Northern plantation, it dropped to last. The remaining provenances formed groups which were not significantly different from each other. Therefore, according to these results, only the Bluhnbach and Calimani provenances originating in the Alps and Carpathians, respectively, should be selected for breeding and operational planting programmes for the Northern Carpathians, while all the others would be less useful.

Comparison of total height growth rankings from the nursery test at age six and the field trial at age 14 (Table 6, columns 1 and 7) showed that:

- at age six in the nursery, the four best provenances, highly statistically significant, were Pietrele, Bluhnbach, Gemenele and Calimani, while at age 14 in the field, only Bluhnbach and Calimani provenances kept their positively significant top positions; these two sources should be considered for operational breeding programme;

- the Valea Lalei, Grachen Wallis, Bois-des-Ayes, Sirnitz-Gilendorfer and Pietrosul provenances occupied the bottom ranking at both age six and 14, and they and some others should be culled.

\section{Variation in annual height growth (N)}

With minor exceptions, ranking of provenance mean values for annual height growth from the nursery stage at age 6 was consistent to that from the field test at age 14 (Table 6, columns 4 and 10). Differences between provenances were highly significant $(\mathrm{p}<0.001)$ a trend that, with minor exceptions, was set at field test (Table 3 ). When the rankings were compared the Pietrele and Calimani provenances held their statistically significant top positions at both age six and 14 while Bluhnbach and Gemenele became insignificant at age 14. The Boisdes-Ayes, Sirnitz-Gilendorfer, Grachen Wallis and Pietrosul provenances held the bottom rank at age six and 14 (Table 6, columns 4 and 10),

\section{Variation in number of branches per whorl (N)}

Results of variance analysis indicated highly significant differences $(\mathrm{p}<0.001)$ between provenances for the number of branches per whorl recorded at ages 12,13 and 14 (Table 3). Provenance means for the number of branches per whorl at age 14 ranged from 6.8 for the Pietrosul source to 9.4 for Stana de Rau, a difference of about $39.9 \%$, indicating significant variation, but lower than that from the Southern trial (Table 6, column 13). Also, the Duncan Multiple Range Test showed that, compared to the plantation mean the Stana de Rau and Calimani provenances were significantly $(\mathrm{p}<0.05)$ better in number of branches per whorl than any other provenances in the test. They exceeded the plantation mean by $15.3 \%$ and $13.5 \%$, respectively (Fig. $2 B$ ). In contrast, the Pietrosul provenance held the last position in the rank (Table 6, column 13) and its performance was significantly $(\mathrm{p}<0.05)$ lower than the plantation mean by $17.6 \%$, (Fig. $2 \mathrm{~B}$ ). The remaining provenances formed groups which were not significantly different from each other. Therefore, according to these results from the Northern trial, the Stana de Rau and Calimani provenances should be selected for the future work in the Northern Carpathians while use of the other sources should be discouraged.

\section{Variation in survival (S/N)}

The planted stock was vigorous from the beginning as it was derived from outcrossing. This contributed to a very high survival. Also, because the plantations were established with potted seedlings and because the trials have been fenced, almost all trees have survived at both plantations. At age 14, the mean survival at the Southern and Northern Carpathians amounted to $99.3 \%$ and $99.8 \%$, respectively. Because of this very high survival, the variance analysis carried out at both individual sites (Table 3) and across sites (Table 4) indicated no significant differences between provenances and no significant provenance $\mathrm{x}$ location interactions. Since variation for survival is lacking, no selection decisions can be made.

\section{Phenotypic coefficients of variation $(\mathrm{N})$}

Low to moderate within provenance variation was found for total and annual height growth but variation was high in number of branches per whorl. Northern trial phenotypic coefficients of variation had estimates slightly higher than the Southern trial estimates. Estimates ranged between $12.1 \%$ and $19.3 \%$ in total height growth, $14.7 \%$ and $19.7 \%$ in annual height growth and $21.7 \%$ and $37.9 \%$ in total number of branches per whorl, a mean of $15.0 \%, 16.9 \%$ and $29.3 \%$, respectively (Table 7 ). Therefore, both the breeding and the operational programme can benefit by utilizing between and within provenance selection.

\section{Phenotypic age-age correlations (N)}

At the Northern trial, correlations between variables at successive ages indicated a very clear pattern (Table

Table 7. - Phenotypic coefficients of variation within provenances of cembra pine in the Carpathian filed trials.

\begin{tabular}{|c|c|c|c|c|c|c|}
\hline \multirow{2}{*}{ Prov. } & \multicolumn{3}{|c|}{ Southern Carpathians trial } & \multicolumn{3}{c|}{ Northern Carpathians trial } \\
\cline { 2 - 7 } & H.14 & h.14 & BW.14 & H.14 & h.14 & BW.14 \\
\hline 1 & 12.2 & 13.9 & 24.5 & 12.7 & 16.2 & 26.0 \\
2 & 14.3 & 15.3 & 26.1 & 14.3 & 18.0 & 27.0 \\
3 & 11.0 & 13.6 & 23.8 & 14.8 & 17.2 & 21.7 \\
4 & 14.8 & 14.0 & 27.9 & 13.6 & 16.6 & 28.4 \\
5 & 15.0 & 13.5 & 25.7 & 13.4 & 16.8 & 28.4 \\
6 & 14.2 & 13.1 & 23.0 & 16.7 & 14.7 & 35.2 \\
7 & 14.3 & 13.0 & 23.7 & 13.7 & 16.4 & 28.0 \\
9 & 11.2 & 12.9 & 24.8 & 17.3 & 19.2 & 28.5 \\
10 & 12.5 & 15.4 & 25.0 & 14.0 & 16.8 & 23.0 \\
14 & 13.6 & 16.7 & 31.6 & 12.1 & 15.0 & 31.4 \\
8 & 10.1 & 19.4 & 19.1 & 17.9 & 15.9 & 35.8 \\
11 & 6.9 & 24.3 & 12.7 & 19.3 & 19.7 & 37.9 \\
Mean & 12.5 & 15.4 & 24.0 & 15.0 & 16.9 & 29.3 \\
\hline
\end{tabular}

H.14, h.14 \& BW.14 = the total and annual height growth and number of branches per whorl, respectively, at age 14 . 
Table 8. - Age-age and trait-trait phenotypic correlations for Swiss stone provenances tested in Southern Carpathians (above diagonal line) and Northern Carpathians (below diagonal line) trials. Age-age correlations were inserted inside rectangles while traittrait ones were inserted outside rectangles.

\begin{tabular}{|c|c|c|c|c|c|c|c|c|c|c|c|c|c|c|c|c|c|c|c|c|c|c|c|c|c|}
\hline Traits & & H. 4 & H.6 & H.7 & H.10 & 1.11 & H.12 & t.13 & H.14 & h. 4 & h. 6 & h.7 & h.10 & h.11 & h.12 & h. 13 & b.14 & RCD.4 & $\mathrm{RCD} .6$ & RCD. 7 & RCD.10 & RCD. 12 & BW. 12 & BW. 13 & BW.14 \\
\hline H. 3 & & 0.93 & 0.91 & 0.88 & 0.82 & 0.78 & 0.73 & $\underline{0.63}$ & $\underline{0.63}$ & 0.93 & 0.89 & 0.87 & 0.51 & $\underline{0.61}$ & $\underline{0.64}$ & 0.56 & 0.50 & 0.92 & 0.93 & 0.89 & $\underline{0.68}$ & $\underline{0.65}$ & $\underline{0.69}$ & .25 & 0.14 \\
\hline H. 4 & 0.93 & & 0.99 & 0.98 & 0.90 & 0.88 & 0.82 & & 0.76 & 0.5 & 0.96 & 0.97 & 0.57 & 0.72 & 0.74 & $\underline{0.63}$ & $\underline{0.66}$ & 0.95 & 0.97 & 0.97 & 0.82 & & 75 & 08 & .21 \\
\hline Н. 6 & 0.91 & 0.98 & & 1.00 & 0.93 & 0.91 & 0.86 & 0.81 & 0.79 & 0.96 & 0.99 & $\underline{0.63}$ & 0.74 & 0.74 & 0.75 & $\underline{0.67}$ & $\underline{0.66}$ & 0.93 & 0.95 & 0.95 & 0.78 & $\delta 1$ & 0.77 & 02 & .26 \\
\hline H. 7 & 0.88 & 0.98 & 0.99 & & 0.94 & 0.92 & 0.88 & 0.83 & 0.82 & 0.94 & 0.99 & 0.99 & $\underline{0.66}$ & 0.77 & 0.77 & $\underline{0.67}$ & $\underline{0.68}$ & 0.91 & 0.94 & 0.95 & 0.80 & 0.53 & 0.81 & .01 & 0.28 \\
\hline H. 10 & 0.85 & 0.83 & 0.80 & 0.80 & & 0.97 & 0.97 & 0.97 & 0.93 & 0.84 & 0.93 & 0.94 & 0.83 & 0.86 & 0.89 & 0.80 & 0.83 & 0.85 & 0.89 & 0.92 & 0.85 & 0.00 & 0.86 & 0.16 & 0.44 \\
\hline H.11 & 0.88 & 0.90 & 0.90 & 0.90 & 0.95 & & 0.97 & 0.96 & 0.95 & 0.83 & 0.92 & 0.91 & 0.85 & 0.93 & 0.87 & 0.86 & 0.87 & 0.82 & 0.85 & 0.88 & 0.84 & 0.0 & 0.85 & 0.33 & 0.55 \\
\hline H.12 & 0.86 & 0.80 & 0.79 & 0.79 & 0.93 & 0.92 & & 0.95 & 0.98 & 0.75 & 0.87 & 0.87 & 0.91 & 0.92 & 0.95 & 0.86 & 0.91 & 0.76 & 0.79 & 0.83 & 0.7 & $0 . \%$ & 0.91 & 0.29 & 0.58 \\
\hline H.13 & 0.89 & 0.87 & 0.84 & 0.84 & 0.95 & 0.96 & 0.97 & & 0.97 & $\underline{0.69}$ & 0.81 & 0.81 & 0.87 & 0.92 & 0.88 & 0.93 & 0.91 & $\underline{0.70}$ & 0.73 & 0.77 & 0.80 & 0.88 & 0.82 & 0.50 & $\underline{0.67}$ \\
\hline H.14 & 0.87 & 0.86 & 0.84 & 0.84 & 0.89 & 0.93 & 0.95 & 0.97 & & $\underline{0.68}$ & 0.81 & 0.81 & 0.92 & 0.95 & 0.95 & 0.91 & 0.96 & $\underline{0.70}$ & 0.72 & 0.76 & 0.7 & 0.80 & 0.87 & 0.45 & $\underline{0.69}$ \\
\hline h.4 & 0.93 & 0.96 & 0.97 & 0.94 & 0.79 & 0.84 & 0.82 & 0.82 & 0.81 & & 0.96 & 0.92 & 0.52 & $\underline{0.63}$ & $\underline{0.66}$ & 0.57 & 0.54 & 0.94 & 0.96 & 0.92 & $\underline{0.71}$ & 0.40 & $\underline{0.66}$ & -0.15 & 0.22 \\
\hline h. 6 & 0.88 & 0.95 & 0.99 & 0.98 & 0.78 & 0.90 & 0.85 & 0.82 & 0.84 & 0.95 & & 0.98 & $\underline{0.66}$ & 0.75 & 0.77 & $\underline{0.67}$ & $\underline{0.67}$ & 91 & 0.93 & 0.92 & & & 0.79 & & 0.33 \\
\hline h.7 & 0.87 & 0.97 & 0.98 & 0.99 & 0.82 & 0.92 & 0.83 & 0.85 & 0.85 & 0.92 & 0.97 & & $\underline{0.64}$ & 0.76 & 0.77 & $\underline{0.67}$ & $\underline{0.67}$ & 90 & 0.93 & 0.95 & & & 280 & 01 & 0.25 \\
\hline h. 10 & 0.57 & $\underline{0.67}$ & $\underline{0.66}$ & $\underline{0.68}$ & 0.79 & 0.79 & $\underline{0.61}$ & $\underline{0.70}$ & $\underline{0.59}$ & $\underline{0.58}$ & $\underline{0.63}$ & $\underline{0.70}$ & & 0.90 & 0.87 & 0.84 & 0.92 & 0.48 & 0.53 & 0.57 & 0.5 & 0.76 & 0.83 & .45 & $\underline{0.76}$ \\
\hline h.11 & 0.85 & 0.86 & 0.87 & 0.88 & 0.78 & 0.93 & 0.90 & 0.87 & 0.90 & 0.77 & 0.88 & 0.88 & $\underline{0.66}$ & & 0.84 & 0.88 & 0.96 & $\underline{0.63}$ & $\underline{0.65}$ & $\underline{0.71}$ & 0.7 & $\underline{0.82}$ & 0.83 & 0.51 & $\underline{0.67}$ \\
\hline h.12 & $\underline{0.70}$ & $\underline{0.63}$ & $\underline{0.67}$ & $\underline{0.66}$ & $\underline{0.60}$ & 0.70 & 0.81 & 0.76 & 0.83 & $\underline{0.65}$ & $\underline{0.70}$ & $\underline{0.65}$ & $\underline{0.60}$ & 0.75 & & 0.85 & 0.89 & $\underline{0.70}$ & 0.72 & 0.73 & & & 0.86 & D.26 & $\underline{0.66}$ \\
\hline h.13 & 0.89 & 0.88 & 0.81 & 0.83 & 0.90 & 0.92 & 0.92 & 0.97 & 0.97 & 0.82 & 0.83 & 0.85 & $\underline{0.59}$ & 0.86 & 0.81 & & 0.93 & 0.57 & $\underline{0.59}$ & $\underline{0.61}$ & $\underline{0.66}$ & 85 & $\underline{0.68}$ & $\underline{0.59}$ & 0.79 \\
\hline h. 14 & 0.81 & 0.84 & 0.87 & 0.84 & $\underline{0.69}$ & 0.81 & 0.78 & 0.81 & 0.88 & 0.79 & 0.82 & 0.86 & 0.47 & 0.87 & 0.76 & 0.87 & & 0.56 & 0.57 & $\underline{0.62}$ & $\underline{0.68}$ & 0.85 & 0.76 & $\underline{0.58}$ & 0.77 \\
\hline RCD.4 & 0.92 & 0.95 & 0.93 & 0.91 & 0.83 & 0.87 & 0.83 & 0.89 & 0.88 & 0.94 & 0.89 & 0.90 & $\underline{0.67}$ & 0.82 & $\underline{0.66}$ & 0.88 & 0.85 & & 0.99 & 0.96 & 0.82 & 0.46 & $\underline{0.68}$ & -0.14 & 0.14 \\
\hline RCD.6 & 0.93 & 0.97 & 0.95 & 0.94 & 0.85 & 0.89 & 0.84 & 0.89 & 0.87 & 0.96 & 0.91 & 0.93 & $\underline{0.70}$ & 0.83 & $\underline{0.63}$ & 0.87 & 0.85 & 0.99 & & 0.98 & 0.85 & 0.48 & $\underline{0.72}$ & -0.13 & 0.16 \\
\hline $\mathrm{RCD} .7$ & 0.89 & 0.97 & 0.94 & 0.95 & 0.84 & 0.90 & 0.82 & 0.87 & 0.86 & 0.92 & 11 & 0.95 & 0.75 & 0.86 & $\underline{0.60}$ & 0.85 & 0.86 & 0.96 & 0.98 & & 0.91 & 0.53 & $\underline{0.71}$ & 0.02 & 0.17 \\
\hline RCD. 10 & $\underline{0.65}$ & 0.56 & 0.52 & 0.52 & 0.77 & $\underline{0.65}$ & $\underline{0.59}$ & $\underline{0.65}$ & 0.53 & 0.55 & 0.45 & 0.52 & $\underline{0.66}$ & 0.46 & 0.19 & 0.53 & 0.37 & 0.57 & $\underline{0.63}$ & $\underline{0.63}$ & & 0.72 & $\underline{0.64}$ & .26 & 0.27 \\
\hline RCD. 12 & 0.72 & $\underline{0.70}$ & $\underline{0.69}$ & 0.70 & 0.86 & 0.79 & 0.81 & 0.85 & 0.79 & $\underline{0.71}$ & $\underline{0.68}$ & $\underline{0.70}$ & $\underline{0.59}$ & $\underline{0.59}$ & $\underline{0.66}$ & 0.79 & 0.54 & $\underline{0.71}$ & 0.73 & 0.73 & $\underline{0.70}$ & & $\underline{0.59}$ & 0.77 & 0.76 \\
\hline BW.12 & 0.76 & 0.76 & 0.77 & 0.79 & 0.82 & 0.90 & 093 & 0.91 & 0.92 & $\underline{0.69}$ & so & 0.80 & $\underline{0.55}$ & 0.88 & 0.88 & 0.90 & 0.75 & 0.72 & 0.72 & 0.73 & 0.41 & 0.78 & & 0.11 & 0.44 \\
\hline BW.13 & $\underline{0.62}$ & & $\underline{0.60}$ & & & 0. & 0. & & 0.80 & & & $\underline{0.65}$ & & & 0.81 & 0.8 & $\underline{0.63}$ & 0.58 & 0.56 & 0.58 & 0.24 & $\underline{0.70}$ & 0.92 & & $\underline{0.70}$ \\
\hline BW.14 & 0.44 & 0.54 & 0.52 & 0.54 & 0.35 & 0.52 & 0.56 & 0.56 & $\underline{0.66}$ & 0.44 & 0.57 & 0.55 & 0.24 & $\underline{0.66}$ & $\underline{0.69}$ & $\underline{0.61}$ & $\underline{0.64}$ & 0.55 & 0.50 & 0.52 & -0.21 & -0.31 & $\underline{0.67}$ & $\underline{0.71}$ & \\
\hline
\end{tabular}

The underlined phenotypic correlations are significant $(\mathrm{p}<0.05)$, while the italic in bold correlations are highly significant $(\mathrm{p}<0.01: \mathrm{p}<0.001)$.

8). Age-age phenotypic correlations for all tested traits were significant $(\mathrm{p}<0.05)$ or highly significant $(\mathrm{p}<0.01$; $\mathrm{p}<0.001)$ in all but two cases indicating that early selection for each trait may be efficient. The age-age correlations for total height were higher than those for the other traits. These results clearly indicate that early selection for all traits may be efficient.

It is apparent that for cembra pine selection for growth traits can be accomplished after a few years of field testing, reducing both the effort and cost for the breeder. Early selection increases the efficiency of an operational tree improvement programme by reducing the funding required for field testing to obtain the same or slightly greater genetic gain (LOWE and VAN BUIJTENEN, 1989). Initially, selection in progeny tests of forest trees was delayed until approximately one-half of the projected rotation age. Recent work has indicated that adequate estimates of rotation age performance can be obtained at much earlier ages (LAMBETH et al., 1983). For the southern pines in the United States, most selection is currently done between five and ten years of age (LOWE and VAN BUIJTENEN, 1989).

\section{Phenotypic trait-trait correlations $(\mathrm{N})$}

The trait-trait correlations are presented in table 8. With the exception of age three, the trait-trait phenotypic correlations between total height growth, successive annual height growth, root collar diameter, and number of branches per whorl were significant $(\mathrm{p}<0.05)$ or highly significant $(\mathrm{p}<0.01 ; \mathrm{p}<0.001)$ in most cases. The correlations between annual height growth and other traits were lower than those correlations previously mentioned. In many cases, a lack of significance was found between annual height growth and successive root collar diameter and number of branches per whorl. Also, in most cases, the root collar diameter was not significantly correlated with number of branches per whorl. Consequently, with minor exceptions, the results suggest that indirect selection may be applied for the two major traits, total height growth and number of branches per whorl.

Correlations between main traits and geographic coordinates $(\mathrm{S} / \mathrm{N})$

Correlations between total height growth and number of branches per whorl at age 14 with geographic coordinates of provenance origins, including the ecophysiological latitude, showed that (Table 9):

- at both the Southern and Northern Carpathian trial, no significant phenotypic correlations were found between total height growth and any of the geographic coordinates, including ecophysiological latitude suggesting that at this stage of the experiment the pattern of variation in growth could be classified as non- clinal; meaning that provenances from Alps could be planted in Carpathians;

- at both Southern and Northern Carpathian trials significant $(\mathrm{p}<0.05)$ negative correlations $(\mathrm{r}=-0.62$; -0.64) were found between number of branches per whorl and altitude, suggesting that the number of branches per whorl follow a clinal pattern of variation;

- at both Southern and Northern Carpathian trials significant $(\mathrm{p}<0.05)$ positive correlations $(\mathrm{r}=0.65$; $r=0.67$ ) were found between number of branches per whorl and longitude, suggesting an east-to-west trend in number of branches per whorl; but, in relation with the latitude and ecophysiological latitude, the number of branches per whorl did not follow any significant clinal pattern. 
Table 9. - Phenotypic correlations between total height growth (H.14) and geographic coordinates and number of branches per whorl (BW.14) and geographic coordinates for Southern and Northern Carpathians.

\begin{tabular}{|l|l|l|l|l|l|l|l}
\hline Trait & Coordinate & Southern & Northern & Trait & Coordinate & Southern & Northern \\
\hline H.14 & Latitude & -0.29 & -0.17 & BW.14 & Latitude & -0.13 & -0.40 \\
H.14 & Le & -0.29 & -0.17 & BW.14 & Le & -0.14 & -0.40 \\
H.14 & Longitude & 0.33 & 0.22 & BW.14 & Longitude & $0.65^{*}$ & $0.67^{*}$ \\
H.14 & Altitude & -0.43 & -0.36 & BW.14 & Altitude & $-0.62^{*}$ & $-0.64^{*}$ \\
\hline
\end{tabular}

Le = ecophysiological latitude.

This study to define patterns of geographic variation as a basis for selecting seed sources and for developing seed transfer guidelines was clearly needed before the inception of a programme for genetic improvement of cembra pine.

\section{Regression (S/N)}

Most tree improvement programmes are geared towards the improvement of several traits at the same time, i. e. to apply multitrait selection. Independent culling is a method of multitrait selection that involves setting minimum values for each trait of interest. Individuals must meet these minimum criteria if they are to be retained (ZOBEL and TALBERT, 1984). By extrapolation from individuals to populations, this method was applied to the present experiment. As previously stated,

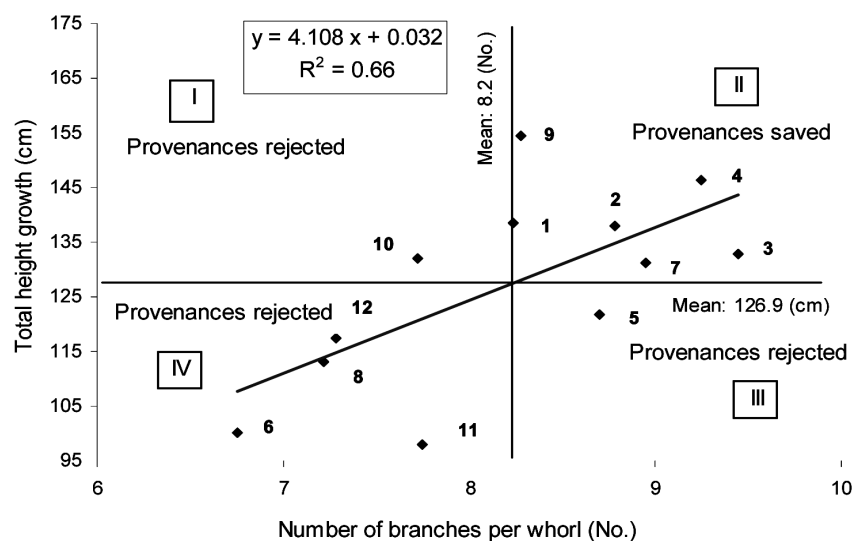

Figure 3. - Regression between the total height growth and number of branch per whorl of cembra pine at the Southern Carpathians trial.

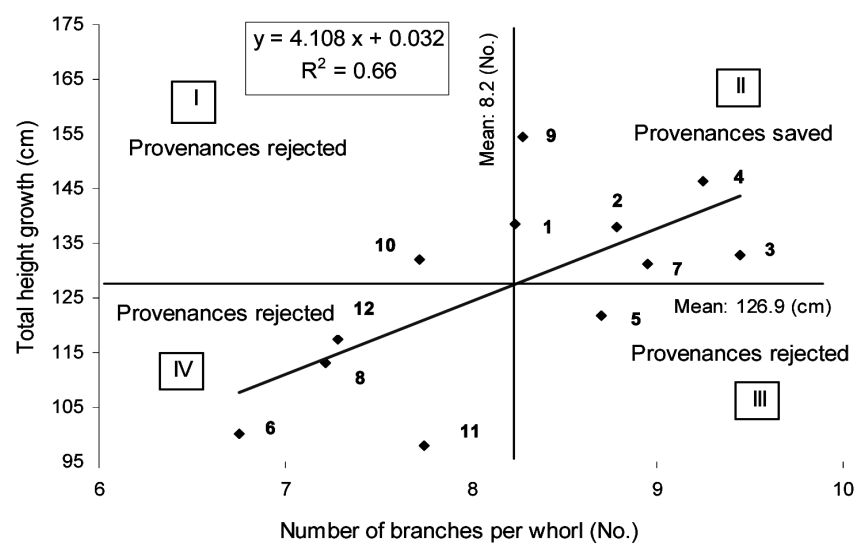

Figure 4. - Regression between the total height growth and number of branch per whorl of cembra pine at the Northern Carpathians trial. from an ecological standpoint height growth and number of branches per whorl are the most important traits. As these traits were significantly positively correlated, indirect selection may be applied.

Regression analysis at age 14 designated which provenances exhibited the faster growth and had a minimum acceptable number of branches per whorl. Provenances like Pietrele and Calimani should be selected and used for the Southern Carpathians (Fig. 3) while Bluhnbach and again Calimani are best for the Northern Carpathians (Fig. 4, quadrant II). It should be pointed out that between the two traits priority was given to the height growth.

Age trend in height growth across sites $(\mathrm{S} / \mathrm{N})$

Figure 5 displays the age trend in height growth at the two trials. A consistent parallel pattern of both total and annual height growth at the Southern and Northern Carpathian trials was evident. During the entire field testing period, total and annual height growth from the Southern Carpathian trial was superior to those from the Northern Carpathian trial. The soil conditions at the two sites were similar while the climatic conditions differ. The average annual temperature is lower and the growing season is shorter at the Northern Carpathians relative to the Southern Carpathians, and this no doubt explains the differences in height growth. Growth from age four to twelve showed a consistent increase in mean annual height, but at age 14 the trees seemed to reach maximum mean annual growth.

\section{Practical implications}

The present experiment was conducted to detect the genetically most appropriate provenances to be planted

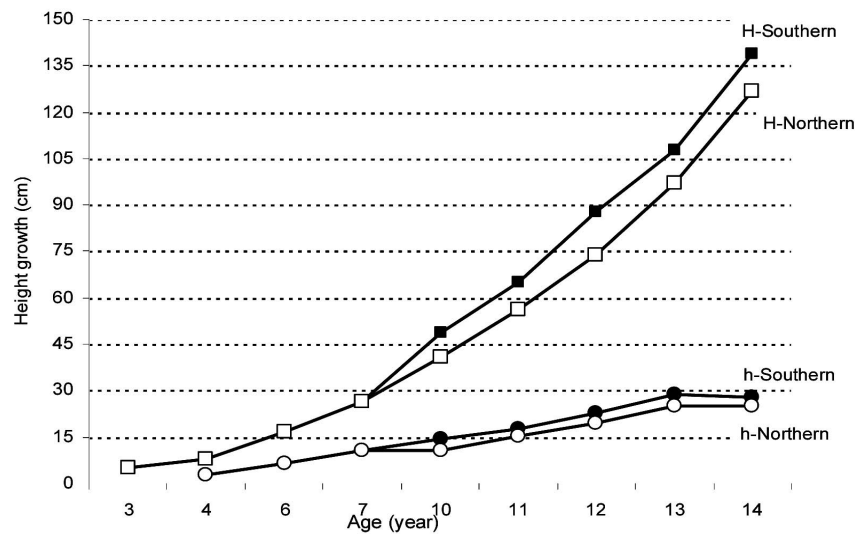

Figure 5. - Age trend in site mean annual (h) and total $(\mathrm{H})$ height growth of the cembra pine at the Southern and Northern Carpathian trials. 
at high elevation in the Carpathians. The best provenances are those that showed both fast growth and larger number of branches per whorl. Due to their faster growth and more branches per whorl, such provenances and individuals within provenances should be planted in the Carpathians because they have the ability to more quickly colonize the area and to play a significant role in preventing avalanches, soil erosion, and downstream flooding. The DuncAN Multiple Range Test and the regressions between total height growth and number of branches per whorl indicated that: the Pietrele, Calimani, Stana de Rau and Gemenele provenances could be recommended for reforestation in the Southern Carpathian while Bluhnbach and Calimani in the Northern ones. It should be stressed that due to its ecological plasticity or low genotype $\mathrm{x}$ environment interaction, the Calimani provenance originating in Northern Carpathians may be planted in both Northern and Southern ones.

\section{Conclusions}

- Though very slow growing, the cembra pine exhibited significant variation not only in growth traits but in number of branches per whorl, as well; therefore, genetic selection at provenance level can be applied.

- The significant and highly significant age-age phenotypic correlations for growth traits and number of branches per whorl clearly suggested that early selection may be efficient; this indicate that selection could be started after field testing

- The significant and highly significant trait-trait phenotypic correlations between height growth and number of branches per whorl suggested that indirect selection may be applied;

- The significant positive correlation between number of branches per whorl and longitude, suggested an eastwest trend in number of branches per whorl;

- The significant negative correlation between number of branches per whorl and elevation suggested that the number of branches per whorl follow a clinal pattern of variation.

- The non significant correlations between total height growth and the geographic co-ordinates suggested that at this stage of the experiment the pattern of variation in growth could be classified as non clinal. Thus, some provenances from Northern Carpathians can be used in the Southern ones and the Carpathians provenances could be planted in the Alps and vice versa;

- The local Pietrele provenance was the best in height growth in the Southern Carpathians while the Bluhnbach provenance originating in the Austrian Alps was the most productive in the Northern Carpathians. As second in the rank, the Calimani provenance can also be taken into account in both Northern and Southern Carpathians.

\section{Acknowledgements}

The considerable contribution of others has to be acknowledged. Dr. CHUCK TAUER, professor at Oklahoma State University reviewed and significantly improved the manuscript. His help is greatly appreciated. The authors thank to Dr. H. KASPER (Switzerland), Dr. H. P. LANG, Dipl. Ing. J. NATHER (Austria), Dr. R. Amat and Mr. FouRNIER (France) for supplying seed from the Alps Mountains. Dr. N. Popescu, Mr. S. Tanasie, Mr. A. DragiLA, Mrs. C. Dinu, Mr. G. SARBU and Mr. D. Pepelea significantly contributed to seed collection from the Carpathians; field trial lay out and field testing. Our sincere gratitude goes to them. Also, we thank Forest Engineer. I. BALASA from the Cugir Forest District and Forest Engineers V. SolOvastru and C. TURCANU for their contribution to the trials' management.

\section{Literature}

BELDIE, A. (1941): Observatii asupra vegetatiei lemnoase din Muntii Bucegi. Analele ICEF, Seria 1, Vol. 6: 39-43.

Bingham, R. T. (1972): Taxonomy, crossability and relative blister rust resistance of 5 needle white pines, pp. 271-280. In: BinghAM, R. T. et al. (Eds.). Biology of rust resistance in forest trees. USDA For. Serv., Misc. Publ., $1221,681 \mathrm{p}$.

BlADA, I. (1987): Genetic resistance to Cronartium ribico$l a$ and height growth in some five needle pines and in some interspecific hybrids. Ph. D. Thesis, Academy of Agricultural and Forestry Sciences, $146 \mathrm{p}$.

BLADA, I. (1990): Genetic variability of some traits in two Pinus cembra natural populations, pp. 56-68. In: GARRET, P. W. (Ed.). Proc. of a symposium on white pines provenances and breeding, North-eastern For. Exp. St., Gen. Tech. Rep. NE-155, 105 p..

BlaDA, I. (1994): Interspecific hybridization of Swiss stone pine (Pinus cembra L.). Silvae Genetica 43 (1): 14-20.

BlaDA, I. (1996): Breeding of Pinus cembra and its nursery and planting operations. Annual Report, No. A.26, Forest Res. Inst., Bucharest, 5 p. (Unpublished).

BlaDA, I. (1997): Stone pine (Pinus cembra L.) provenance experiment in Romania: I Nursery stage at age 6 . Silvae Genetica 46 (4): 197-200.

BladA, I. (1999): Diallel crossing in Pinus cembra: III Analysis of genetic variation at the nursery stage. Silvae Genetica 48 (3-4): 179-187.

BlaDA, I. and N. Popescu (1994): Variation in size and weight of cones and seeds in four natural populations of Carpathians stone pine, pp. 54-58. In: ScHMIDT, C. W., et al. (Eds.). Proceedings international workshop on sub-alpine stone pines and their environment. USDA For. Serv., Intermountain Res. St., INT-GTR-309, 321 p.

CEAPOIU, N. (1968): Metode statistice aplicate in experimentele agricole si biologice. Ed. Agro-Silvica Bucuresti, $550 \mathrm{p}$.

Contini, L. and Y. LAVAREllo (1982): Le pin cembro. INRA, Paris. 197 p.

CRitchfield, W. B. and L. LitTLE, JR. (1966): Geographic distribution of the pines of the World. Misc. Publ. 991, Washington, USDA For. Serv., $97 \mathrm{p}$.

DunCAN, D. B. (1955): Multiple range and multiple Ftests. Biometrics 11: 1-42.

GuBESH, L. (1971): Raspandirea relictului glaciar zambrul (Pinus cembra) pe versantii sudici ai unor massive din Calimani. Ocrotirea Naturii 15 (2) pp. 149-159.

Hoff, R. J., R. T. Bingham and G. I. McDonald (1980): Relative blister rust resistance of white pines. Eur. Jour. For. Path. 10(5): 307-316.

Holzer, K. (1972): Intrinsic qualities and growth potential of Pinus cembra and Pinus peuce in Europe, pp. 99-110. In: Bingham, R. T. et al. (Eds.). Biology of rust resistance in forest trees. USDA For. Serv., Misc Publ., $1221,681 \mathrm{p}$. 
Holzer, K. (1975): Genetics of Pinus cembra L. Anales Forestales, 6 / 5, Zagreb, $158 \mathrm{p}$.

Lambeth, C. C., J. P. van BuiJtenen and S. Duke (1983): Early selection is effective in 20-year-old genetic tests of loblolly pine. Silvae Genetica 32 (5-6): 210-213.

Lowe, W. J. and J. P. VAN BUIJTENEN (1989): The incorporation of early testing procedures into an operational tree improvement program. Silvae Genetica 38 (5-6): 242-250.

Mirov, N. T. (1967): The genus Pinus. New York, Ronald Press Comp., 602 p.

OARCEA, Z. (1966): Contributii la cunoasterea si vegetarii pinului cembra in Retezat. Revista Padurilor 9: 495-497.

RIKLI, M. (1909): Die Arve in the Schweiz. Denkschrift Naturf. Gesellschaft 44, 455 p.
SchmidT, W. C. (1994): Distribution of stone pines, p. 1. In: Schmidt, W. C and Holtmeier, F. K. (Eds) Proc. Int. Workshop on Sub-alpine Stone Pines and Their Environment, Intermountain Res. Station, Tech. Rep. 309.

Tataranu, I. D. and C. Costea (1952): Un arbore de interes forestier: Pinus cembra. Revista Padurilor 11: $3-14$.

van BuiJtenen, J. P. and J. L. Yeiser (1989): Exercises in quantitative genetics of forest trees. Student Book, Texas A\&M University106 p.

VIERSMA, J. H. (1962): Enkete kwantitatieve aspecten van het exotenvraagstuk. Nederlands Bosbouw Tijtschrift 34 (5): 175-184.

Zobel, B. and J. TALBERT (1984): Applied forest tree improvement. John Wiley \& Sons, New York, 505 p.

\title{
Comparative Analysis of Karyotypes from the Strezelecki Ranges Race of the Complex Eucalyptus globulus Labill. ssp. globulus (Myrtaceae) and a Population in Central-Southern Chile
}

\author{
By J. Espejo CARDemil ${ }^{1)}$ and C. BAeza Perry ${ }^{2), *}$
}

(Received 12 $2^{\text {th }}$ April 2006)

\begin{abstract}
Summary
This study presents information on karyotypes of the Strezelecki Ranges race, referred to in previous studies as Jeerelangs (Victoria, Australia), of the complex Eucalyptus globulus. ssp globulus and another from CentralSouthern Chile (Contulmo). The chromosomes counted $(2 \mathrm{n}=22)$ are fairly small-sized and found within the size ranges reported by other authors. The chromosome measurements, done with the Micromeasure program, indicate that the Strezelecki Ranges lineage has a relatively large genome (Total Chromosome Length $=8.94 \%$ ) as compared to measurements of local lineages (Chile). This could be explained by genetic recombinations resulting from the successive hybridizations reported for this race. The data obtained for both lineages reveal a set of markedly metacentric chromosomes with a centromeric index between 0.44 and 0.46 .
\end{abstract}

Key words: Eucalyptus globulus, Myrtaceae, karyotype, chromosomes, land race, Chile, Australia.

\section{Introduction}

The study of karyotypes is a valuable tool for comparing species and discriminating between populations (MATSumoto et al., 2000; Schrader et al., 2000;

\footnotetext{
1) Programa Magíster en Ciencias Forestales. Universidad de Concepción.

2) Departamento de Botánica. Universidad de Concepción.

*) Corresponding Author: Telephone \#: (56-43) 220-3879; Fax \#: (56-43) 224-7060; Email: cbaeza@udec.cl.
}

Schrader et al., 2003). STEBbins (1971) indicated that the majority of this woody angiosperm's chromosomes are very small and that small differences exist between the species within the genus. The report of the Eucalyptus globulus Labill. chromosome recount done by BoLKHOVsKiKH et al., (1969) showed that $82 \%$ of the counts done for the species of this genus had a karyotype of $2 \mathrm{n}=22$ chromosomes. In a cytological study, RYE (1979) reported that up to $90 \%$ of the species studied have the same number of chromosomes. Eucalyptus has been described as a very large genus, with over 700 species (PoKE et al., 2006). In cline variations and hybridizations are very common and can be verified within the subgenera (PRYOR, 1976).

The first systematic cytological studies of Eucalyptus globulus pollen grains began in the 1930s (MCAULAY et al., 1936; MCAULAY and CRUICKSHANK, 1937); these studies reported a haploid number for the species of $\mathrm{n}=11$. Later, BEDI (1989) and MoRA et al., (2005) carried out new chromosome counts for this species using material taken from root tips. The latter authors also analyzed the E. globulus karyotype and found that the chromosomes fluctuated between $1.42 \pm 0.4 \mu \mathrm{m}$ in length.

No karyotype characterization studies have been done to discriminate between $E$. globulus sub-species and races, mostly because of the methodological complexity of obtaining metaphase plates from the very small chromosomes $(<2 \mu \mathrm{m})$ that characterize this species and genus (Atchinson, 1947; RYE, 1979; HAQUe, 1984; HARBARD, 1995, 1996; MATSUMOTO et al., 2000). JoRDAN et al. 